\title{
Effective Self-Regulating Teams: A Generative Psychological Approach
}

Lynne J. Millward, Adrian Banks and Kiriaki Riga

\author{
Department of Psychology \\ School of Human Sciences \\ University of Surrey \\ Guildford \\ Surrey, GU2 7HX, UK \\ Tel: +44 (0) 1483689442 \\ Fax: +44 (0) 1483300803 \\ e-mail: L.Millward-Purvis@surrey.ac.uk
}

Key words: Self-Regulating Teamwork, Context, Team Identification, Shared Mental Models, Collective Efficacy, Team Task Reflexivity, Constructive Debate.

Classification: Conceptual Paper

Manuscript Word Count: 7,541 words including Appendix 


\title{
Effective Self-Regulating Teams: A Generative Psychological Approach
}

\begin{abstract}
This paper compliments Hackman's (2002) work on the critical conditions for effecting 'self-regulated' teamwork with an understanding of team psychology. Assuming various structural pre-requisites, we propose that effective teamwork is generated by a social self-identification process, upon which there are 'emergent states' across affective (commitment, cohesion), motivational (drive to secure and maintain positive self-esteem), cognitive (shared cognition) and behavioural (intra-team and inter-team processes) dimensions. This propositional model integrates and builds on previous thinking into a more generative understanding of effective team work (i.e., what makes teamwork possible and how can this be sustained) that takes into account the importance of context in accounting for team success. Considerations for further testing, conceptual and methodological refinement are highlighted. The model otherwise affords clear pragmatic implications for leveraging more effective teamwork in organizational contexts.
\end{abstract}


This paper offers a more generative understanding of effective teamwork (i.e., what makes teamwork possible and how can this be sustained) that integrates and builds on previous work by Hackman $(1998 ; 1999 ; 2002)$ taking into account the critical importance of context in accounting for team success. First we defend the need for a more generative approach by reflecting critically on existing models. Secondly, we review the literature on relevant 'generative' concepts applicable to team level working, and evolve a set of propositions that link these together in a testable way. Finally we produce some recommendations for how to apply the propositional model to the practice of developing more effective teamwork.

\section{Understanding Team Working}

Team work is a well established design strategy for organizing coordinated flexible work that in principle should yield a synergy benefit (i.e., achieving more than the sum of their individual parts), but more commonly does not even achieve the summative criterion (Burke, Stagl, Salas, Pierce \& Kendall, 2006; Hackman \& Wageman, 2005). The prevailing input-process-output (I-P-O) framework depicts the team as a relatively closed system with controllable inputs (e.g., task, team, individual characteristics) and outputs (team performance) managed by various 'processes' in between (van Knippenberg \& Schippers, 2007). Recently, organizational considerations (e.g., organizational support, management practices) as potential moderators have also been factored into the 'input' equation (e.g., Mathieu, Gilson \& Ruddy, 2006). As the outputs are understood to depend fundamentally on the integrity of the 'team process' (as mediator), much effort has been directed thus (Marks, Mathieu \& Zacarro, 2001 for a review).

Deficiencies in team output are usually attributed to 'process loss' (Steiner, 1972), explanations for which include 'social loafing' (Latane, Williams, \& Harkins, 1979) arising from member disengagement, 'group think' (Janis, 1972), where members endorse the 'consensual' view without constructive debate for fear of reprimand or exclusion (even when the risk of fatal error is high), and intra-team conflict across task (i.e., substantive disagreements about task issues), process (i.e., disagreements about resource allocation) and relationship (i.e., personal disagreements between members) 
dimensions (Jehn, 2008). Conversely, key generic processes linked with the most effective team performance are cooperative intra-team interaction, information sharing and communication (Haslam, 2004).

It is however, increasingly being recognised that team work processes are differentially associated with performance depending on project phase (e.g., planning, implementation), phase of team development, and in relation to different tasks across different contexts (Williams \& Allen, 2008). Moreover, and most fundamental of all, are findings showing that process-focused interventions have no reliable impact on team success which is difficult to reconcile with a process-dominated perspective on teams (e.g., Peterson, Owens \& Martorana, 1999).

One explanation is that the link between team processes and outputs is much more complex than envisaged by the I-P-O model, and that there are in fact 'team level' psychological mediators which Marks, et al. (2001) refer to as 'emergent states' (see also Mathieu, Gilson \& Ruddy, 2006). Emergent states denote member attitudes, values, motivations and cognitions that are said to evolve through the process of interacting as a team (i.e., process emergent) with implications for performance, and that can be studied in their own terms. Research has since begun to identify specific emergent states that facilitate orchestrated team action. Examples of affective states include commitment (e.g., Bishop \& Scott, 2000), cohesion (e.g., Molleman, 2005), and psychological safety (e.g., Edmonson, 1999). Examples of cognitive states include shared mental models (Mohammed \& Dumville, 2001) and collective efficacy (Bandura, 1997).

Another explanation for the tenuous process-performance link comes from Ilgen and colleagues (Ilgen, 1999; Ilgen, Hollenbeck, Johnson \& Jundt, 2005). Ilgen et al propose that, in addition to recognising that inputs and outputs are linked via more complex chains of mediation (e.g., emergent states, processes) than originally envisaged, team 'output' is also likely to feed back (i.e., 'input') into the team process (I-M-O-I). Thus team processes may, at least in part, be a consequence of team performance as much as vice versa (Peterson, Owens \& Martorana, 1999). Factors like task complexity, team size and team composition may also play a moderating role (Williams \& Allen, 2008). 
Whilst the I-M-O-I framework is indeed more conducive to understanding the team as a dynamic open-systems entity, it is yet to propose mechanisms that can account for how effective teamwork comes about. Debate about the causal precedence of team process alongside the potential for infinite complexity in the search for relevant mediators and moderators have prompted Hackman and colleagues (Hackman, $1998 ; 1999 ; 2002)$ to question the merits of the 'causal' approach. They reconstruct team effectiveness with reference to factors both inside (i.e., interdependent goal, clarity of purpose, appropriate structure, relevant knowledge) and outside the team (e.g., reward arrangements, resources, how much autonomy is possible, team coaching). Context, in particular, Hackman (2002) says, has the power to disable the performance of an otherwise well-functioning team. From this perspective, team processes have diagnostic value but no ultimate performance leverage.

The pioneering practical significance of Hackman's work on the 'essential' and 'enabling' conditions of effective teamwork will be accented below, but it is his self-governing metaphor of the team that is of particular interest here. Hackman refers in particular to providing "the conditions within which [teams] can chart their own idiosyncratic courses" (Hackman, 1999, p.244) and more "naturally evolve into an ever more competent performing unit” (Hackman, 2002). Such conditions include coaching the team to manage its own internal processes (Hackman \& Wageman, 2005).

Many other eminent writers on teams have long recognised the effective team as being one that is self-regulating particularly in the face of constant change requiring flexibility within the team process (e.g., Mathieu, et al, 2006; Vera \& Crossan, 2005). The self-regulating team, 1) takes responsibility for, and control of, its own processes in relation to contextual needs including self-correction (see especially, Smith-Jenstch, Cannon-Bowers, Tannenbaum \& Salas, 2008), 2) is proactive in shaping its context as well as responding to it, and 3), that can improvise and innovate. Terms like 'heedful interrelating' attempt to capture this self-regulating quality (Druskat \& Pescosolido, 2002).

\section{The Generative Basis of Effective Team Work}

Whilst Hackman (2002) addresses well the question of how a team's natural self-governance can be promoted and supported, little is known about the generative basis of this potential, nor how teams can 
regulate their own internal processes. Our paper is directed thus. Firstly, a generative model is proposed to address the question of how team work is possible. Secondly, a self-regulating principle is introduced that can explain how teams can monitor and manage their own processes. Hackman's (2002) 'essential' and 'enabling' conditions provide important building blocks for our generative model. Relevant existing concepts and findings from the 'causal' literature are also parsimoniously integrated into our model. Our aim is 'simplify' our causal understanding rather overcomplicate as well as to account for the fundamental role played by context in team success.

\section{Proposition 1 Essential Structural Conditions}

We propose, like Hackman (2002) that there are some 'essential' conditions for team work without which teamwork is not possible ${ }^{1}$. These conditions are: a material mandate for interdependence in relation to some attractive and achievable common goal (Proposition 1a), and an appropriate infrastructure including interdependent role organization (Proposition 1b) and team-level rewards (Proposition 1c).

Proposition 1a: Many teams fail because they have no clear 'team goal' (Hackman, 2002).

Extensive research documents the performance-enhancing impact of goal setting among both individuals (e.g., Locke \& Latham, 2002) and teams (e.g., Yearta, Maitlis, \& Briner, 1995). Goals focus attention and energize goal-relevant activities, predicting persistence in the face of obstacles. However, for goals to motivate there must first be some goal commitment, prerequisite to which is that the goal is perceived as attractive and achievable, and secondly the team must have the necessary capability, experience and knowledge. Feedback is also crucial to sustaining goal commitment, and in guiding the adjustment of behavior towards success. Thus, for team members to act in a coordinated goal-directed manner, they must all be clear about what they are expected to achieve and on their role in relation to this, they must want to achieve the goal, and

\footnotetext{
${ }^{1}$ Many team events fail to achieve any performance benefits for this reason alone: such teams are merely 'rhetorical' teams, with no material necessity to work as a team (Hackman, 2002).
} 
perceive this to be possible from both a team, and organizational perspective (necessary team and organizational resources), and they must accept this as a meaningful basis for performance evaluation against tangible milestones.

Proposition 1b: Giddens (1984) postulates that all behaviour has a structural basis: if coordinated action is required then team structure should support this. Structure is a set of rules (e.g., roles, norms) and resources (e.g., human, material) that make certain types of action possible (see also Hackman, 2002).

Proposition 1c: Members must also experience team-level rather than individual-level rewards, otherwise individuals will pursue their own goals at the expense of the common goal (Morhman, Cohen \& Morhman, 1995; Tjosvold, West \& Smith, 2003; West \& Markiewicz, 2003). A supportive organizational infrastructure will manage teams 'as teams' rather than collections of individuals (Hackman, 2002).

\section{Proposition 2. Generative Psychological Conditions for Teamwork: Mechanisms of Identification}

Goal interdependencies create psychological imperatives for coordinated action to the extent that they provide a basis for social identification. Interdependence is not sufficient in itself to create this psychological imperative. Proposition 1a holds that all team members must recognise and accept the interdependent nature of their relationship in the pursuit of a shared goal. Proposition 2 maintains that goal interdependence must furnish a meaningful and attractive social self-category with which to identify (Proposition 2) (Abrams, Hogg, Hinkle \& Otten, 2005; Tajfel, 1978; Haslam, 2004). This proposition holds across all types of teams irrespective of whether there is spatial or temporal co-presence (i.e., colocated and virtual teams). So long as members are minded they are a team, they will constitute a team with generative psychological presence (Abrams, et al 2005). 
Team identification as a form of social self-categorisation denotes an individuals' internalization of the 'team' as part of their self-definition (Haslam, 2004). Through social identification the way someone thinks (cognition), feels (affect) and behaves is qualitatively transformed through a self-stereotyping process. In this way, thinking, feeling and behaving will represent and protect the integrity of the team's interests. Social identifications are however highly context sensitive and must remain psychologically salient to sustain their generative influence. Salience is about the psychological accessibility of a social identity and has two dimensions: comparative and normative. Comparatively, a particular social category must make sense to an individual as a basis for self-definition and evaluation, relative to other potential identifications. As such it must provide an unequivocal basis for securing meaning and self-esteem within the organization.

Normatively speaking, the social category must also be aligned with everyday behavioural imperatives and reward structures (consistent with Proposition 1c).

It is generally accepted that employees can and do identify strongly with organizational teams and that these identifications can be chronically salient as a generative influence on behaviour (e.g., Millward, Haslam, \& Postmes, 2007). Whilst in principle, a team can have a psychological presence without any physical instantiation (i.e., temporal and spatial presence) regular face-to-face intra-team interaction will consolidate and sustain the team in the longer-term (Brown \& Millward, 1993; Deaux \& Martin 2003; Fiol \& O’Connor, 2005; Millward, et al, 2007; Postmes, Haslam, Swaab, 2005). Intra-team interaction is in fact crucial to harnessing the synergy benefits of teamwork (Propositions 3-6).

This issue of salience is also critical to Proposition 2. People may be objectively tied by a common goal, and/or by interdependent task imperatives but this does not automatically mean that this is subjectively salient as a driver of thoughts, feelings and behaviour. For example, in situations where the 'team' is a superordinate entity comprising multi-disciplinary professional groups, distinctive professional agenda's may be more salient than working interdependently in relation to a common goal (Durkin \& Nigan, 2003). In this case, team identification will need to be actively generated through some viable and attractive salienceenhancing mechanism (e.g., incentivised collective goal) (Haslam, 2004). Haslam, Eggins and Reynolds (2003) demonstrates the potential for sub-group goals and super-ordinate 'team' goals to be mutually salient 
as drivers of behaviour particularly when collaborative rather than competitive norms prevail (see also, Millward \& Postmes, in press; see Proposition 8 below).

Evidence shows team identification has generative outcomes akin to the Marks et al (2001) concept of 'emergent states' across affective (commitment, cohesion), motivational (drive to secure and maintain self-esteem), cognitive (shared goals and shared cognition), and behavioural (intra-team and inter-team processes) dimensions (Haslam \& Ellemers, 2005 for a review). Each of these emergent states is addressed below under Propositions 3-6.

\section{Proposition 3: Affective States - Team Commitment and Team Cohesion}

Affective states (cohesion, commitment) in association with team identification are both well established predictors of a range of team-level motivational and performance outcomes, including working the extra-mile, cooperation and effort on behalf of the team, work satisfaction, reduced absenteeism and turnover (Abrams, Hogg, Hinkle \& Otten, 2004; Bishop \& Scott, 2000; Bishop, Scott \& Burrough, 2000; Cooper-Hamik \& Wiswevaran, 2005). Recently, Høigaard, Säfvenbom and Tønnessen (2006) found that team cohesion (defined as attraction to the team as opposed to particular members therein) prevented the likelihood of social loafing among 118 soccer players. Affective commitment (defined as an emotional attachment to the team) on the other hand, is a strong predictor of the desire to stay (Meyer \& Allen, 1997), and is arguably an affective dimension of social identification (Ellemers, De Gilder \& Haslam, 2004). In short, affective states not only relate positively to indicators team performance they are 'sustainability' factors, contributing fundamentally to team maintenance and stability (Ellemers, 2001).

\section{Proposition 4 Motivational States - Collective Efficacy}

One of the central propositions of Self-Categorisation Theory is that identity is motivated by a desire to secure and maintain positive self-esteem through strategies of positive inter-group differentiation (i.e., to secure positive distinctiveness). However, it is now well recognised that identity can work in other esteem enhancing ways which need not be so exclusive (Abrams et al, 2004). In addition to 
distinctiveness, Breakwell (1993) identified two other identity principles in the service of self-esteem, which are continuity, and efficacy. Continuity is an identity principle that is most likely to become important to the extent that the stability of identity is threatened. Securing efficacy ${ }^{2}$ on the other hand is likely to be especially important in work contexts. As there is now a wealth of evidence on the predictive significance of 'collective efficacy' in team contexts, we focus our review accordingly. Proposition 4 is hence that team identification will predict a strong motivation to secure and maintain collective efficacy in organizational contexts.

A team's belief in its effectiveness as a performance predictor was first noted by Sayles (1958) but only became the focus of any substantive empirical investigation during the late 1980's (e.g., Larson \& La Fasto, 1989; Shea \& Guzzo, 1987). Collective efficacy denotes “a group's shared belief in its conjoint capabilities to organise and execute the courses of action required to produce levels of attainment" (Bandura, 1997; see also Jung \& Sosik, 2003) in relation to a specific task or task situation. One other label commonly used to describe team efficacy is 'team potency' (e.g., Guzzo et al, 1993) referring to a more generic member belief in team effectiveness (i.e., across tasks and situations) (e.g., Gully et al, 2002). Accordingly, collective efficacy is found to be a stronger predictor of domain specific team performance than team potency (e.g., Chen, Gully \& Eden, 2001). Whilst in practice both collective efficacy and team potency may influence team processes in similarly optimising ways (Jung \& Sosik, 2003), evidence suggests that they probably have different effects and should be distinguished conceptually (Guzzo et al., 2002; Katz, et al. 2005).

Although differing in their levels of analysis, Bandura (1997) maintains that self and collective efficacy have similar sources, serve similar functions and operate through similar processes. It is nonetheless important to note that collective efficacy is a team level construct rather than an aggregate of individual levels of self-efficacy (Zaccaro et al, 1995). Collective efficacy leads a team to establish higher goals, to exert more effort in the pursuit of these goals and to demonstrate greater persistence in case of any failure or negative feedback (e.g., Peterson, Mitchell, Thompson \& Burr, 2000) which aligns with

\footnotetext{
${ }^{2}$ In practice, all three principles are likely to be highly interrelated in the way they drive group/team behaviour.
} 
Proposition 1a). Marks (1999), has also reported improved inter-member coordination in teams with high efficacy with beneficial consequences for performance of especially novel tasks. Tape recordings of team process showed that teams (3-person simulated tank command teams) with high collective efficacy were more strategic and adjusted themselves to the needs of the task (e.g. through role re-assignment, altered communication).

Perceived success is also likely to consolidate team identification (Riggs \& Knight, 1994): as Pierce et al (2002) put it, collective efficacy and performance are reciprocally and longitudinally linked. Baker (2001) also found that members learn from each others positive team experiences and form expectations accordingly (see also, Guzzo et al 1993). Watson, Chemers and Preiser (2001) showed that collective efficacy can be based on perceptions of individual member proven efficacy in newly formed (e.g., sports) teams, but will eventually evolve its own supra-ordinate reality (with a correspondingly weakening impact of self-efficacy on team performance). Finally there is also some evidence showing that collective efficacy early on in a team process can furnish the development of shared mental models (Peterson et al., 2000) suggesting that shared mental models may in part mediate the impact of collective efficacy on performance.

From the above, it is possible to elaborate on Proposition 4 as follows: firstly, both team identification and collective efficacy will be reciprocally bolstered by perceived team success (Proposition 4a); secondly, collective efficacy will be positively associated with team task proficiency with positive benefits for team outcomes (across both routine and complex tasks) assuming that measurement is domain specific for both predictor and criterion (Proposition $4 b$ ); thirdly, the effect of collective efficacy on team process will be at least partially mediated by shared team mental models (Proposition 4c), especially early on in a team's development (Proposition 4d).

\section{Proposition 5. Cognitive States -Shared Cognition}

As team identification is predicated on perceived interdependence in relation to a common goal, Proposition 5 holds that this will motivate the team to develop the appropriate knowledge to achieve this 
goal. Some form of shared cognition is indeed now commonly agreed to be important to effective teamwork but the plethora of different concepts used to explain how collective effort can be optimised (e.g., collective cognition, cognitive consensus, information sharing, shared mental models, transactive memory) can be confusing. Our focus is on the 'shared mental model' because of its relatively more developed conceptual basis, rapidly increasing empirical support and greater clarity of implications for team development (Mohammed \& Dumville, 2001). Mental models allow people to draw inferences, make predictions, understand phenomena, decide which action to take and experience events vicariously. As Druskat and Pescosolido (2002) put it shared mental models are conceptualisations of the bases of action (see also, Griepentrog \& Fleming, 2003).

Applied to collective contexts, it has been found that when relevant content within mental models is shared, members are better able "to coordinate their actions and adapt their behaviour to demands of the task and other team members" (Cannon-Bowers et al. 1993; Cooke, Kiekel, Salas, Stout, Bowers, \& Cannon-Bowers, 2003; Marks, Zaccaro, \& Mathieu, 2000; Mathieu, Heffner, Goodwin, Salas, \& CannonBowers, 2000). Most research has been conducted on two particular aspects of shared knowledge: task (e.g., McItyre \& Salas, 1995; Mohrman, 2003) and team knowledge (e.g., Druskat \& Pescosolido, 2002; Hirschfeld, Jordon, Field, Giles \& Armenakis, 2006; Lankau \& Scandura, 2002) with some work looking simultaneously at shared knowledge of both task and team (e.g., Mathieu, et al, 2000; Fleming \& Griepentrog, 2003).

Task mental models can pertain to both general (e.g., medical knowledge base) and specific (e.g., particular practices) task knowledge (Cannon-Bowers \& Salas, 2001). A team-based mental model on the other hand refers to knowledge of team member expertise, preferences, strengths, weaknesses and experiences, as well as knowledge of team interaction processes. Both sub-team models are assumed necessary to enable "an agent to develop a higher-level abstraction about the capabilities, expertise, and responsibilities of other team members" (Yen, Fan, Sun, Hanratty, \& Dumer, 2006: 636) such that all contributions can be harnessed effectively in relation to the task. 
Evidence shows that the greater the knowledge convergence within both task and team models, the better the team process (translating inputs into outputs) and the better the performance (see for instance, Mathieu et al, 2000). Team members who share a model of the team and team task will be better able to predict what each other are going to need and do, particularly in situations where time and also communication opportunities are limited (Mathieu et al, 2000). This assumes of course that what knowledge is shared, is also accurate (Edwards, Day, Arthur and Bell, 2006).

There is debate however about the extent to which it is necessary to share all task knowledge for teamwork to be effective. Cannon-Bowers and Salas (2001) make four structural distinctions: overlapping (e.g., common understanding of disease to facilitate reliable diagnosis), similar or identical (i.e., attitudes and beliefs that help team members 'make sense' of a situation in a similar way), compatible or complementary (e.g., different specialist knowledge contributing to a common goal) and distributed (i.e., knowledge required to complete a complex task is apportioned among inter-dependent members to reduce the work load). Banks and Millward (2000) found that it was distributed compatible rather than shared knowledge which accounted for performance improvements in their simulated navigation task.

Subsequent studies suggest that the way knowledge is most optimally distributed will depend on the task. Whilst it is debatable whether in fact different types of knowledge (declarative, procedural) are more or less amenable to sharing (e.g., procedural knowledge or knowledge of how to perform a task is more likely to be specialised) (Banks \& Millward, 2007), most agree that there may be complex task conditions under which the most optimal team strategy is to both share and distribute knowledge to minimise individual cognitive overload (Edwards, Day, Arthur \& Bell, 2006; Griepentrog, \& Fleming, 2003; Yen, Fan, Sun, Hanratty, \& Dumer, 2006). In support, Griepentrog and Fleming (2003) found that shared - as in similar or identical mental models, were only related to performance in less complex tasks requiring a high degree of interdependence. This finding, based on a meta-analysis of 21 effect sizes across 1089 teams, suggests that distributed but compatible knowledge may be more appropriate to the complex task mental model. 
Distributed task knowledge may in turn imply a stronger need for a shared team model such that all members are minded of 'who knows what', particularly insofar as divergence in task knowledge may also correspond with less time spent communicating (see for example, Levesque et al, 2001). Indeed, a recent study described by Hirschfeld et al (2006) found that better mastery of 'teamwork knowledge' predicted better team task proficiency among US Air Officers in relation to a complex training task and higher observer ratings of effective teamwork after controlling for the former.

There has been relatively less work on the development of SMM but from the work of Klimoski and Mohammed (1994) it can be viably surmised that the increased intra-team interaction, cooperation and communication associated with team identification will be conducive to sharing knowledge about team capabilities and task requirements. Accordingly, SMM will be time-served rather than an immediate outcome of team identification (Klimoski \& Mohammed, 1994; Kraiger \& Wenzel, 1997).

Proposition 5 thus holds that team identification will play a generative role in furnishing shared team (and where relevant, also task) mental models, because team identification heightens intra-team interaction, cooperation and communication in relation to the shared goal. In turn, and from the discussion above, it is expected that, accurate shared team mental models will predict team task proficiency (team process) which will mediate better team outcomes (Proposition 5a), especially in relation to complex team tasks where specialist knowledge is distributed across members (Proposition 5b). Finally, it is expected that accurate shared task mental models will be strongly positively associated with team task proficiency under conditions of low task complexity (i.e., where task knowledge should be similar rather than distributed) (Proposition 5c).

\section{Proposition 6. Behavioural Processes - Intra-Team and Inter-Team Processes}

Team identification predicts pro-team activities like inter-member cooperation, heightened intrateam interaction, information sharing and communication (e.g., van Dick 2004, van Knippenberg and van 
Schie 2000; Millward et al, 2007). As discussed above, such processes in turn consolidate team identification, collective efficacy, shared mental models, commitment and cohesion.

It is important to note however that team identification can also have a dark side (Haslam, 2004). From an intra-team perspective, it can furnish group-think and over-conformity to team-serving norms which may or may not be conducive to task performance (Haslam, 2004). This is most likely to happen in response to dominant leadership, where alternative viewpoints are not permissible. Such internal dynamics can have fatal consequences (e.g., Helmreich \& Foushee, 1993). Jehn's (2008) work tells us that in some circumstances, task conflict is conducive to team outcomes. From an inter-team perspective, team identification can also be exclusive, creating intergroup conflict and competition. In some contexts, this can be performance-conducive (e.g., sales teams) (Millward \& Postmes, 2008), but in others it may undermine performance by inhibiting collaboration and sharing (Haslam, 2004). However, none of the darker side of team identification is inevitable (Haslam, 2004). To this extent, Proposition 7 holds that some reflective mechanism is required to harness and optimise the generative potential of team identification whilst also keeping in check its 'darker side'. Proposition 8 on the other hand, identifies some of the 'normative' conditions (collaborative norms, psychological safety) necessary for constructive reflection to occur.

\section{Proposition 7 Self-Governing Teams - Team Task Reflection}

Pivotal to our proposed model is that the team will be most effective when it manages its own internal processes. This can be undertaken through a reflective process (see for example, Schon, 1983) (Proposition 7). However, active reflection must be systematically instigated and managed. Reflection can not only pre-empt or address negative team processes (group think, social loafing, intra-team conflict, negative response to repeated failure) it can facilitate more strategic action and also learning from mistakes (Proposition 8).

Terms like 'reflexive' and 'critical' thinking which now abound in the educational literature (e.g., Georghiades, 2004 for a review), have begun to permeate the performance literature (e.g., Hodgkinson \& Sparrow, 2002; West, 1996; 2000). West and colleagues in particular, have been programmatic in their 
endeavour to look closely at the role played by 'reflexivity' in team effectiveness (Carter \& West, 1998; West, 1996; 2000). West (1996: 559) defines reflexivity as "the extent to which group members overly reflect upon the group's objectives, strategies, and processes and adapt them to current or anticipated endogenous or environmental circumstances".

Evidence suggests that especially in team situations, strategic thinking is critical to helping teams find the best ways to address the problems they are facing (e.g., Hackman, 2002; Schwenk, 1988) but unfortunately, teams tend to develop their strategies early on, or do not reflect upon them, particularly under time constraints and pressure to 'deliver' (e.g., Hackman \& Wagerman, 2005). Ironically however a production emphasis at the expense of strategy development is not always conducive often leading to exceeded project deadlines (e.g., Tukel and Rom, 1998). The focus of reflection is thus on, a) increasing a team's strategic focus, and, b) improving its strategy (involving the ability to select, organize and adapt actions to changing task situations) (Marks, Mathieu, \& Zaccaro, 2001). Critical success strategies in team situations include knowledge integration and sharing expertise (e.g., Hackman, 2002; Marks, et al, 2001; Salas, Sims, \& Burke, 2005; Sicotte \& Langley, 2000) and problem solving (e.g., Socotte \& Langley, 2000).

The emerging literature strongly supports the relationship between team reflexivity and team effectiveness in real world team scenarios (see for example, Schippers, Den Hartog, Koopman, \& Weink, 2003; Tjosvold, Hui, \& Yu, 2003), building largely on the work of Carter \& West (1998). In their study of 19 BBC TV production teams, Carter and West (1998) demonstrated a positive link between a selfreport measure of task reflexivity (e.g., this team often reviews its objectives, how well we communicate is often discussed) and team effectiveness (as independently judged against audience appreciation ratings). Higher levels of team reflexivity have also been associated with higher innovation potential in situations of high task ambiguity and environmental uncertainty (e.g., De Drue, 2002; Gurtner et al, 2006; Tjosvold, Tang \& West, 2004). Hoegl and Parboteeah (2006) also confirmed a positive relationship between team reflexivity and team effectiveness across 145 software teams after controlling for team size, project type and organizational location. 
In operational terms, team reflexivity is evident through discussion about strategy (Marks et al, 2001; West, 2000). West (2000) argues that there are three stages to the reflexive process: reflect on past performance to consider potential improvements, develop new strategies and how to implement new strategies, and implementing new strategies. On this basis, the team should have experience of a task before they can reflect upon their strategies vis-à-vis the task; in fact, continual reflection is even more important to the experienced team to prevent them from becoming locked into a particular way of approaching a task (e.g., Hackman \& Wagerman, 2005). Teams can vary in how much they habitually reflect but can also be taught to reflect through a guided process (e.g., Gurtner et al, 2006).

Recent studies are beginning to identify more precisely the conditions under which reflexivity (as defined here) relates most strongly to effectiveness. For example, Gevers, van Eerde and Rutte (2001) demonstrated that high reflexivity was more strongly related to performance at the implementation phase (i.e., at a stage in a project where habitual reflection is least likely). Hoegl and Parboteeah (2006) likewise argue that reflexivity requires time and resources and could undermine efficiency at some stages in a project life cycle. This requires the team to be strategic in its use of reflexivity (i.e., reflective use of reflexivity) and points to a role for the leader as meta-monitor of its team's reflexive practice (Moreland \& Levine, 1992; see also De Dreu \& West, 2001; De Dreu, 2002).

The role of the leader would also be critical to ensuring that discussion is not focused on 'common ground' at the expense of considering exceptions (Moreland \& Levine, 1992; see Proposition 8 on constructive debate), to prevent lapsing into groupthink (West, 2000). Gurtner et al (2006) highlight the importance of maintaining a balance of individual and team reflexivity as a means of tempering the likelihood of a team to focus on the general and the common. Findings also show that the reflexive process involves better communication and awareness of team member strengths, weaknesses and contributions, which in turn can enhance the clarity of team mental models.

Clearly, for reflexivity to have a performance promoting impact it should be a constructive process (e.g., accepting responsibility, learning from what works as well as what does not work, action oriented), rather than a negative one (e.g., involving blame, ruminative rather than action-based). A team 
which has a high rather than a low collective efficacy is more likely to be constructive in its reflection because it is more predisposed to be positive, goal and action oriented (Bandura, 1997).

Thus we propose that an effective team reflects on its internal processes and in so doing, makes direct improvements to both task and team knowledge and indirect improvements to team process. Specifically, constructive task-reflexivity will be strongly positively associated with team outcomes especially during the implementation phase of a project (Proposition 7a), positively associated with shared team mental models (Proposition 7b) and also collective efficacy (Proposition 7c).

\section{Proposition 8 Self-Governing Teams II: Learning Environment and Constructive Debate}

Proposition 8 holds that for team task reflexivity to be used to most optimal effect in organizational settings, there must be a climate of learning and constructive debate. Edmonson's (2004) concept of 'psychological safety' pertains to a micro-culture of openness in which learning through mistakes is possible, rather than a culture in which mistakes are hidden. Openness will facilitate reflection on what went wrong, how and why to identify root causes so that pre-emptive action can be taken.

Jehn's (2008) work on conflict importantly also shows how task conflict can, under some conditions, be important to team outcomes (e.g., climate of constructive debate) particularly during the planning stages, and in preventing groupthink. In some instances, consensus may be optimising but in others, definitely not (e.g., when alternative perspectives need to be constructively aired) as in high risk situations that can threaten health and safety (e.g., Bay of Pigs disaster, Challenger disaster, aircraft fatalities) (Brown, 2000). Task conflict can also, if constructively managed, be conducive to improving the clarity of team and task mental models through the process of reckoning openly with explicit differences among team member (Endsley \& Pearce, 2001). The term 'constructively managed' is a crucial caveat to task conflict which could otherwise easily transmute into interpersonal conflict with deleterious team consequences (Jehn \& Bendersky, 2003). A climate of 'psychological safety' (and collaborative norms) is likely to be fundamental to whether genuinely constructive debate around task issues is possible and to what effect (Tjosvold, 2007).

\section{DISCUSSION AND FUTURE DIRECTIONS}


The focus of this review is on the generative nature of effective team work rather than behavioural processes, integrating research on emergent states, and on the assumption that the most effective team is self-governed (Hackman \& Morris, 1975; Hackman, 2002; Sundstrom et al, 2000), within reasonable organizational limits. It is the first systematic effort ${ }^{3}$ to integrate all relevant concepts with both explanatory and predictive power into a formal propositional model that has direct pragmatic implications for practice.

The concepts described and defended not only stand alone as viable explanatory tools but arguably also interrelate in systematic ways (i.e., relational rules can be specified and tested) that add value overall, therefore also affording greater power to leverage effective teamwork. Nonetheless, there are some issues to address as cautionary caveats to the practice implications of our model.

\section{Conceptual considerations}

It is highly likely that in field contexts team members will deploy multiple coexisting shared mental models to complete any one team task (Cook et al, 2003; Lim \& Klein, 2003; Levesque et al 2001; Mathieu \& Schulze, 2006; Smith-Jentsch, Mathieu \& Kraiger, 2005). Smith-Jentsch, Mathieu and Kraiger (2005) found that team and task mental models among air traffic controllers each had a unique effect on team process and performance (see also Mathieu et al, 2000). Webber, Chen, Pain, Marsh and Zaccaro (2000) however found that the interrelationship between task and team models depends on how 'sharedness' is measured (e.g., agreement or consistency).

On the issue of content, the idea of a 'team interaction model' is commonly assimilated to the general rubric of a team mental model. However, the former has a 'meta-cognitive' definition (e.g., Swaab \& Postmes, 2007) insofar as it informs members how they ought to behave towards each other and how to share control over the task and how to prevent and correct problems. If there is validity in the claim that meta-cognitive training can enhance the content and application of a team interaction model (Marks et al 2000; Ensley \& Pierce, 2001) then this may be an important prerequisite to 'team reflexivity'. Other concepts like 'team situation awareness' (Cooke, Stout, \& Salas, 1997) might also be

\footnotetext{
${ }^{3}$ To our current knowledge.
} 
prerequisite for 'team reflexivity'. Notwithstanding the possibility of conceptual overlap, it is clear that some kind of 'heedful relating' is important to effective teamwork (Weick \& Roberts, 1993; Druskat \& Pescolido, 2002).

It is likewise possible that collective efficacy (or team potency) is a shared belief within a general mental model (Watson, Chemers \& Preiser 2001). Druskat and Pescolido (2002) identified three main 'belief based' models of relevance to effective teamwork as follows: sense of personal ownership over team work processes and outcomes, belief in continuous learning as prerequisite for heedful relations and self-correction), and recognition of the need for interdependence and interconnected action (SmithJentsch, et al, 2008). At least the first (acceptance of ownership) and the third of these beliefs (acceptance of interdependence) are an inextricable part of what it means to be identified with the team. Shared belief in continuous learning however is more akin to Edmonson's (2004) concept of 'psychological safety' as articulated in Proposition 8 (see Argote, 1993 on 'capturing learning'). Hypotheses like this are testable within the proposed model.

\section{Methodological Considerations}

The testability of our model presupposes:- 1) operational as well as conceptual clarity and precision, and 2) some independent means of evaluating effectiveness. Under the first bracket, there are commonly used self-report indicators of team identification (e.g., Haslam, 2004 for review), collective efficacy (e.g., Bandura, 1997) and team reflexivity (e.g., West \& Carter, 1998; West, 2000), with proven reliability and reliability.

Measuring shared ness in mental models is however a little more controversial (e.g., Cooke, Kiekel, Salas, Bowers, Stout, Cannon-Bowers, 2003; Mohammed, Klimowski, \& Rentsch, 2000). Most research uses an index of agreement but others use similarity in content as criterion (see Langan-Fox, Code \& Langfield-Smith, 2000 for comprehensive review). Mohammed et al (2000) argued that the most important point here is that researchers must clearly justify their choice of measurement.

Finally, when considering team effectiveness, there is a very real need for increased clarity of the criterion domain across the varied contexts in which team performance is the issue (Millward, 2005). This 
pertains to the need to be clear about what exactly we are trying to predict and explain when we talk about building more effective teams.

\section{Team Development Implications}

The above offers a framework within which to hang the team building/development enterprise with both scientific integrity and practical leverage. The key pragmatic principle arising from our model is that team interventions are addressed to the 'causes' of optimal team behaviour, rather than team behaviour itself. Whereas traditional teambuilding is largely about changing team process (Figure 2), the cognitive-motivational approach advocates a step back in the inquiry process to ask more fundamental questions about 'What makes team behaviour possible?' and 'How is optimal team functioning brought about?' (Figure 3). Our model specifically directs the team intervention to:- a) the promotion of a team focus and orientation as a prerequisite to team effectiveness and $b$ ) the promotion of team competence at cognitive (team mental models), meta-cognitive (higher-order reflective) and motivational levels (team identification and team potency). Each of these intervention foci are addressed in more detail in Appendix 1.

However, it is also crucial to now that the necessary organizational infrastructure MUST be in place to support this intervention, as none of our psychological principles will make sense outside of the wider structural and normative framework in which teams are located. In other words, there must be a real task imperative underlying team focus and orientation.

The approach evolved from our model strongly advocates the use of team skill training (e.g., team reflexive ability). It is highly unlikely that any of the components of the proposed model can be built within a one-shot workshop type forum even where this is complemented by one or two on-site follow up sessions. What is most critical is that the intervention will need to facilitate team ownership and responsibility for the team process. Where possible team leaders can be trained to facilitate the team development process in their own teams, drawing on outside help to 'compliment' their approach (e.g., team skills training) rather than vice-versa. 
Our focus on how effective teamwork can be generated and sustained is applicable to all types of team, including virtual teams. A virtual team is one that comprises members separated by geographical, organizational and/or temporal distance and uses information and communication technologies to complete the team task ( $\operatorname{Rad} \&$ Levin, 2003). The use of virtual teams has increased substantially in recent years because in principle they should facilitate amalgamation of expert resources by transcending the time and space barrier (McDonough, Kahn \& Barczak, 2001). However, they commonly succumb to process loss, resulting predominantly from communication and relational issues (Timmerman \& Scott, 2006). Successful virtual teams on the other hand operate with a shared sense of team identification and focus (Van Knippenberg \& Schippers, 2007). Indeed, because of their increased focus on task related activities and less on intra-team relations, virtual teams can perform better than collocated teams (Hoegl, Ernst \& Propsperio, 2007).

Full application of the proposed model to team practice will need to reckon with how to promote appropriately shared team and task knowledge. Findings are beginning to confirm that team mental models can be systematically engineered (Kozlowski \& Klein, 2000; Kozlowski \& Bell, 2003; Mathieu, et al. 2000; Mohammed \& Dumville, 2001) by giving information on team member jobs through lecture or discussion, role observation and discussion or hands-one role rotation with noteworthy performance improvements (e.g., Marks, Sabella, Burke, \& Zaccaro, 2002). Whilst questions remain about the depth of cross-training required to improve team performance, efforts to promote shared knowledge can, and do appear to reap benefits. There is also a question about the sustainability of team mental models across time and their ability in particular to accommodate change, especially in situations with high role and task differentiation with limited opportunities to interact (Druskat \& Pescolido, 2002). The concept of 'team reflexivity' may provide the critical moderator of how mental models play out over time; in this way team training will make it the responsibility of the team to reflect on the accuracy, relevance and effectiveness of their mental models (.g., Mohammed \& Ringseis, 2001).

There is clearly an important role to be played by the leader as a facilitator of team reflexivity and in the use of this to build up collective efficacy by integrating performance feedback into the self- 
correcting cycle (Ilgen, 1999; Watson et al, 2001). Findings show that strong leadership is indeed critical to collective efficacy which is in part also furnished by building team identification (e.g.,

Sivasubramaniam, 2002).

\section{Conclusion}

Our conceptual model assumes that the most effective team is relatively self-governed, reflecting constructively on, and managing its own internal processes. It articulates in particular the generative basis of effective teamwork from both a structural-normative and psychological point of view. The generative basis is necessary though not sufficient for effective teamwork which must be constructively regulated and sustained. The team can take some responsibility for the integrity of its own processes but this will need to be supported by an appropriate organizational infrastructure. 


\section{REFERENCES}

Abrams, D., Hogg, M.A, Hinkle, S., \& Otten, S. (2005), “The Social Identity Perspective on Small Groups" in Poole, S.M., \& Hollingshead, A.B. (Eds.), Theories of Small Groups: Interdisciplinary Perspectives, Sage, Thousand Oaks, CA. pp.99-137.

Argote, L. (1993), "Group and organizational learning curves: individual, system and environmental components", British Journal of Social Psychology, Vol 32, pp.31-51.

Baker, D.F. (2001), “The development of collective efficacy in small task groups”. Small Group Research, Vol 32 No 4, pp. 451-474.

Bandura, A. (1997), The exercise of control, W.H.Freeman, New York, NY.

Banks, A., \& Millward, L.J. (2000), "Running shared mental models as a distributed cognitive process”, British Journal of Psychology, Vol 91, No 4, pp.513-531.

Banks, L.J., \& Millward, L.J. (2007), "Differentiating knowledge in teams: the effect of shared declarative and procedural knowledge on team performance", Group Dynamics: Theory, Research and Practice, Vol 11 No 2, pp. 95-106.

Bishop, J.W., and Scott, K.D. (2000). “An examination of organizational and team commitment”. Journal of Applied Psychology, Vol 85 No 3, pp. 439-450.

Bishop, J., Scott, K., \& Burroughs, S (2000), “Support, Commitment and Employee Outcomes in a team environment", Journal of Management, Vol 26 No 6, pp. 1113-1132.

Breakwell, G.M. (1993), "Social representations and social identity”, Papers on Social Representations, Vol 2, pp. 198-217.

Brown, R.J., \& Millward, J.L (1993), "Perceptions of Group Homogeneity during group formation and change", Social Cognition, Vol 11 No 1 pp.126-149.

Brown, R.J. (2000), Group Processes: dynamics within and between groups, $2^{\text {nd }}$ Edition. Blackwell, Oxford. 
Burke, C.S., Stagl, K.C., Salas, E., Pierce, L., \& Kendall, D. (2006), “Understanding Team Adaptation: A conceptual analysis and model”, Journal of Applied Psychology, Vol 91, pp. 1189-1207.

Cannon-Bowers, J.A., \& Salas, E., (2001), "Reflections on Shared Cognition”, Journal of Organizational Behaviour, Vol 22 No 2 pp. 195-202.

Cannon-Bowers, J.A., Salas, E., \& Converse, S., (1993), Shared mental models in expert decision making, in Castellan, N.J. (ed.), Individual and Group Decision Making, Erlbaum, Hillsdale, NJ.

Carter, A.J., and West, M.A, (1998). "Sharing the burden: Teamwork in health care settings", in: J. FirthCozens, J., and Payne, R. (Eds.), Stress in health professionals: Psychological causes and interventions, Wiley, Chichester, UK, pp. 191-202.

Chen, G., Gully, S., \& Eden, D., (2001). "Validation of a new general self-efficacy scale", Organizational Research Methods, Vol 4 No 1, pp.62-68.

Cooke, N,.J., Kiekel, P.A., Salasm E., Stout, R., Bowers, C., \& Cannon-Bowers, J. (2003). Measuring team knowledge: A window to the cognitive underpinnings of team performance. Group Dynamics: Theory, Research, and Practice, 7(3) 179-199

Cooke, N.J., Stout, R., \& Salas, E. (1997), “Expanding the measurement of situation awareness through cognitive engineering methods", Proceedings of the Human Factors and Ergonomics Society, $41^{\text {st }}$ Annual Meeting, 215-219.

Cooper-Hamik, A., \& Viswesvaran, C. (2005), “The Construct of Work Commitment: Testing an Integrative Framework", Psychological Bulletin, Vol 131, pp. 241-258.

De Dreu, C.K.W., \& West, M. (2001), “Minority dissent and team innovation: the importance of participation in decision making", Journal of Applied Psychology, Vol 86, No 6, pp. 1191-1121.

De Dreu, C.K.W. (2002), “Team innovation and team effectiveness: The importance of minority dissent and reflexivity", European Journal of Work and Organizational Psychology, Vol 11 No 3, 285298.

Deaux, K., \& Martin, D. (2003), “Interpersonal Networks and Social Categories: Specifying Levels of Context in Identity Processes", Social Psychology Quarterly, Vol 66 No 2, pp.101-117. 
Druskat, V.U., \& Pescosolido, A.T. (2002). The content of effective teamwork mental models in selfmanaged teams: ownership, learning and heedful interrelating. Human Relations, 55(3) 283-314.

Durkin,E., \& Nigan, A. (2003) "Is Knowledge Really Shared Across Disciplines?: A Qualitative Study of Interdisciplinary Team Process", Abstr Academy Health Meet,. 20: abstract no. 464.

Edmondson, A. (1999). "Psychological safety and learning behavior in work teams", Administrative Science Quarterly, Vol 44, pp. 350-383.

Edmondson, A. (2004), "Psychological safety, trust and learning: A group-level lens”, in Kramer, R., \&. Cook, K. (Eds.), Trust and distrust in organizations, Sage Russell, New York, NY. Pp. 239-272.

Edwards, B.D., Day, E.A., Arthur, W., \& Bell, S.T. (2006), "Relationships among team ability composition, team mental models, and team performance", Journal of Applied Psychology, Vol 91 No 3, pp. 727-736.

Ellemers, N. (2001), “Social identity, commitment, and work behavior”, in Hogg, M.A., \& Terry, D.J. (Eds.), Social identity processes in organizational contexts, Psychology Press. Pp. 101-114.

Ellemers, N., De Gilder, D., \& Haslam, S.A. (2004), “Motivating individuals and groups at work: A social identity perspective on leadership and group performance", Academy of Management Review, Vol 29, pp. 459-478.

Ellemers, N., Spears, R., \& Doosje, B. (2002), “Self and Social Identity”, Annual Review of Psychology, Vol 53, pp.161-186.

Ensley, N.D., \& Pierce, C.L. (2001), "Shared cognition in top management teams: implications for new venture performance", Journal of Organizational Behaviour, Vol 22, pp.145-160.

Fiol C.M.,\& O’Connor, E.J., (2005), “Identification in Face-to-Face, Hybrid, and Pure Virtual Teams: Untangling the Contradictions", Organization Science, Vol 16 No 1, pp. 19-32.

Fleming, P.J., Wood, G.M., Ferro, G., Bader, P.K., \& Zaccaro, S.J. (2003). The Locus of Shared mental models: whence does the sharedness come? Paper presented at the $18^{\text {th }}$ Annual Conference of the Society of Industrial and Organizational Psychology, April 11-13, Orlando, Florida. 
Georghiades, P., (2004), "From the General to the Situated: Three Decades of Meta-cognition", International Journal of Science Education, Vol 26 No 3, 365-383.

Gevers, M.P., van Eerde, W., \& Rutte, C.G. (2001), "Time pressure, potency, and progress in project groups", European Journal of Work and Organizational Psychology, Vol 10 No 2, pp. 205-221.

Giddens, A. (1984), The Constitution of Society: Outline of the Theory of Structuration, Polity, Cambridge, UK.

Griepentrog, B.K., \& Fleming, P.J. (2003), “Shared mental models and team performance: are you thinking what we're thinking?" Paper presented at the $18^{\text {th }}$ Annual Conference of the Society of Industrial and Organizational Psychology, April 11-13 ${ }^{\text {th }}$, Orlando, Florida.

Gully, S.M., Incalcateerra, Joshi, A., \& Beaubien, J.M. (2002), “A meta-analysis of team efficacy, potency, and performance: interdependence and level of analysis as moderators of observed relationship", Journal of Applied Psychology, No 5, pp. 819-832.

Gurtner, A., Tschan, F., Semmer, N.K., \& Nagele, C. (2006), “Getting groups to develop good strategies: Effects of reflexivity interventions on team process, team performance, and shared mental models", Organizational Behaviour and Human Decision Processes, Vol, 102 No 2, pp. 127-142.

Guzzo, R.A., Yost, P.R., Campbell, R.J., and Shea, G.P. (1993), "Potency in groups: articulating a construct”, British Journal of Social Psychology. Vol 32, No 1, pp. 87-106.

Gully, S.M., Incalcaterra, K.A., Joshi, A., Beaubien, J.M. (2002), “A meta-analysis of team efficacy, potency, and performance: interdependence and level of analysis as moderators of observed relationship", Journal of Applied Psychology, Vol 87 No 5, pp. 819-832.

Hackman, J. R., \& Morris, C. G. (1975), “Group tasks, group interaction process, and group performance effectiveness: A review and proposed integration", in Berkowitz, L.(Ed.), Advances in experimental social psychology, Vol 8, Academic Press, New York, NY.

Hackman, J.R., \& Wageman, R. (2005)," When and how team leaders matter", Research in Organizational Behaviour, Vol 26, pp. 37-74. 
Hackman, J.R. (1998), “Why teams don't work”, in Tindale, R.S., et al., (Eds.) Theory and research on small groups, Plenum Press, New York, NY.

Hackman, J.R. (1999), “Thinking differently about context”, in Wageman, R. (Ed.), Groups in context, JAI Press, Stamford, CT.

Hackman, J.R. (2002), Leading teams: Setting the stage for great performances, Harvard Business School Press, Boston, US.

Haslam, S. A. \& Ellemers, N. (2005), "Social identity in industrial and organizational psychology: Concepts, controversies and contributions", in Hodgkinson, G.P. (Ed.) International Review of Industrial and Organizational Psychology, (Vol.20). Chichester: Wiley.

Haslam, S. A. (2004), Psychology in organizations: The Social Identity Approach (2nd ed). Sage, London, UK.

Haslam, SA., Postmes. T., \& Ellemers, N. (2003), "More than a metaphor: Organizational Identity makes organizational life possible", British Journal of Management, Vol 14, pp. 357-369.

Haslam, S.A., Eggins, R.A., Reynolds, K.J. (2003), "The ASPIRe model: actualizing social and personal identity resources to enhance organizational outcomes", in Haslam, S.A., van Knippenberg, D., Platow, M.J., Ellemers, N. (Eds), Social Identity at Work: Developing Theory for Organizational Practice, Psychology Press, Philadelphia, PA, pp.241-57.

Helmreich, R. L., \& Foushee, H. C. (1993), “Why Crew Resource Management? Empirical and theoretical bases of human factors training in aviation", in Wiener, E.L., Kanki, B.G., \& Helmreich, R.L. (Eds.), Cockpit Resource Management, Academic Press, San Diego, CA.

Hirschfeld, R.R., Jordon, M.H., Field, H.S., Giles, W.F., \& Armenakis, A.A. (2006). Becoming team players: Team Members’ Mastery of Teamwork Knowledge as a Predictor of Team task Proficiency and Observed Team work Effectiveness. Journal of Applied Psychology, 91(2), 467474

Hodgkinson, G. P., \& Sparrow, P.R. (2002), The competent organization: A psychological analysis of the strategic management process. Open University Press, Buckingham. 
Hoegl, M., \& Parboteeah, K.P. (2006). Team reflexivity in innovative projects. R\&D Management, 26(2) $113-125$

Hoegl, M., Ernst, H., \& Prosperio, L. (2007). How team work matters more as team member dispersion increases. Journal of Product Innovation Management, 24, 156-165

Høigaard, R., Säfvenbom, R. \& Tønnessen, F. E. (2007), “The relationship between group cohesion, group norms, and perceived social loafing in football”, Small Group Research, Vol 37, pp.217232.

Ilgen, D.R. (1999), “Team embedded in organizations: Some Implications”, American Psychologist, Vol 54, pp.129-139

Ilgen, D.R., Hollenbeck, J.R., Johnson, M., \& Jundt, D. (2005), “Teams in organizations: From inputprocess-output Models to IMOI models", Annual Review of Psychology, Vol 56, pp. 517-543.

Janis, Irving L. (1972), Victims of Groupthink, Houghton Mifflin Company: Boston.

Jehn, K. \& Bendersky, C. (2003), "Intra-group conflict in organizations: A contingency perspective on the conflict-outcome relationship", Research in Organizational Behavior, Vol 25, pp. 187-242

Jehn, K., \& Rispens, S. (2008), “Conflict in workgroups”, in Cooper, C.L., and Barling, J. (Eds.), Handbook in Organizational Behavior, Sage, US.

Jung, D.I., \& Sosik, J.J. (2003), “Group potency and collective efficacy”, Group and Organization Management, Vol 28, No 3, pp.366-391.

Katz-Navon, T.Y., \& Erez, M. (2005), "When collective and self-efficacy affect team performance: the role of task interdependence", Small Group Research, Vol 36 No 4, pp. 4370-465.

Klimoski, R., \& Mohammed, S., (1994), “Team Mental Model: Construct or Metaphor?”, Journal of Management, Vol 20, pp. 403-437.

Kozlowski, S. W. J., \& Bell, B. S. (2003), "Work groups and teams in organizations”, in Borman, W.C., Ilgen, D.R., \& Klimoski, R.J. (Eds.), Handbook of Industrial and Organizational Psychology, Vol 12, Wiley, London. pp. 333-375. 
Kozlowski, S. W. J., \& Klein, K.J. (2000), “A multi-level approach to theory and research in organizations: Contextual, temporal and emergent processes", in Klein, K.J., \& Koslowski, S.W.J. (Eds.), Multi-Level theory, research and methods in organizations, Jossey-Bass, San Franscisco, pp.3-90.

Kraiger K and Wenzel LH (1997), “Conceptual development and empirical evaluation of measures of shared mental models indicators of team effectiveness", in Brannick, M.K., Salas, E., \& Prince, C. (Eds.,), Team Performance Assessment and Measurement: Theory, Methods, and Applications, Lawrence Erlbaum Associates, Inc, New Jersey.

Langan-Fox, J., Code, S. L. , \& Langfield-Smith, K. (2000), “Team mental models: Techniques, methods and analytic approaches", Human Factors, 42, pp. 242-271.

Lankau, M. J., \& Scandura, T. A. (2002), “An investigation of person learning in mentoring relationships: Content, antecedents and consequences", Academy of Management Journal, Vol 45, pp.779-790.

Larson, C.E.K., La Fasto, F.M.J. (1989), TeamWork: What Must Go Right/What Can Go Wrong, Sage Publications, Newbury Park, CA.

Latane, B., Williams, K., \& Harkins, S., (1979) "Many Hands Make Light The Work: The Causes and Consequences of Social Loafing”, Journal of Personality and Social Psychology, Vol 37, pp. $822-832$.

Levesque, L.L., Wilson, J.M., \& Wholey, D.R. (2001). Cognitive divergence and shared mental models in software development project teams. Journal of Organizational Behavior, 22, 135-144.

Locke, E. A., \& Latham, G. P. (2002), "Building a practically useful theory of goal setting and task motivation: A 35-year odyssey”, American Psychologist, Vol 57 No 9 pp. 705-717.

Marks, M.A., (1999), 'The impact of collective efficacy in routine and novel performance environments", Human Performance, Vol 12 No 3-4, pp. 295-309.

Marks, M. A., Mathieu, J. E. \& Zaccaro, S. J. (2001), “A temporally based framework and taxonomy of. team processes", Academy of Management Review, Vol 26, pp.356-376. 
Marks, M.A., Sabella, M.J., Burke, C.S., \& Zaccaro, S.J. (2002), “The impact of cross-training on team effectiveness", Journal of Applied Psychology, Vol 85, pp. 273-283.

Mathieu, J. E., \& Schulze, W. (2006), "The influence of team knowledge and formal plans on episodic. team process - performance relationships", Academy of Management Journal, Vol 49 No 3, pp. 605-619.

Mathieu, J.E., Heffner, T.S., Goodwin, G.F., Salas, E. \& Cannon-Bowers, J.A. (2000). The influence of shared mental models on team process and performance. Journal of Applied Psychology, 85(2) $273-283$

Mathieu, J.E., Gilson, L.L., \& Ruddy, T.M. (2006), “Empowerment and team effectiveness: An. empirical test of an integrated model", Journal of Applied Psychology, Vol 91 No 1, pp.97-108.

McDonough, E.F., Kahn, K.B., \& Barczak, G. (2001), “An investigation of the use of global, virtual, and collocated new product development teams", Journal of Product Innovation Management, Vol 18, pp. 110-120.

McIntyre, R. M., \& Salas, E. (1995), “Measuring and managing for team performance: Emerging principles from complex environments", in Guzzo, R., \& Salas, E. (Eds.), Team Effectiveness and Decision Making in Organizations, Jossey-Bass, San Francisco, CA. pp. 149-203.

Meyer, J. P., \& Allen, N. J. (1997). Commitment in the workplace. Thousand Oaks, CA: Sage.

Millward, L.J. \& Jeffries, N. (2001), "The Team Survey: A tool for Health Care Service Development", Journal of Advanced Nursing, Vol 35 No 2, pp. 276-287.

Millward, L.J. (2005). Understanding Occupational and Organizational Psychology, Sage: London, UK. Millward, L.J., \& Postmes, T. (in press), "Who I am affects how I do: The performance benefits of identification", British Journal of Management.

Millward, L.J., Haslam, S.A, \& Postmes, T. (2007), "Putting employees in their place: The impact of hotdesking on organizational and team identification”, Organization Science, Vol 18 No 4, pp.547559. 
Mohammed, S., \& Ringseis, E. (2001), “Cognitive diversity and consensus in group decision making: The role of inputs, processes, and outcomes", Organizational Behavior and Human Decision Processes, Vol. 78, No. 1, pp. 25-62.

Mohammed, S., Klimowski, R., \& Rentsch, J.R. (2000), “The measurement of team mental models: we have no shared schema", Organizational Research Methods, 3, pp.123-145.

Mohammed, S., \& Dumville, B.C. (2001), “Team mental models in a team knowledge framework: expanding theory and measurement across disciplinary boundaries", Journal of Organizational Behaviour, Vol 22, pp.89-106.

Molleman, E. (2005), "Diversity in Demographic Characteristics, Abilities and Personality Traits: Do Faultlines Affect Team Functioning?”, Group Decision and Negotiation, Vol 14 No 3, pp.173193.

Levine, J. M., \& Moreland, R. L. (1992), “Small groups and mental health”, in Ruble, D., Costanzo, P., \& Oliveri, M. (Eds.), The social psychology of mental health: Basic mechanisms and applications, Guilford Press, New York, NY. pp. 126-165.

Morhman, S.A., Cohen, S.G., Morhman, A.M. (1995), Designing Team-Based Organisations: New Forms for Knowledge Work, Jossey-Bass, San Francisco, CA.

Peterson, E., Mitchell, T.R., Thompson, L., \& Burr, R. (2000), "Collective efficacy and aspects of shared mental models as predictors of performance over time in workgroups". Group processes and intergroup relations, Vol 3 No 3, pp. 296-316.

Peterson, R. S., Owens, P. D., \& Martorana, P. V. (1999), “The group dynamics q-sort in organizational research: A new method for studying familiar problems", Organizational Research Methods, Vol 2, pp.107-136.

Pierce, C.L., Gallagher, C.A., \& Ensley, M.D. (2002), "Confidence at the group level of analysis: A longitudinal investigation of the relationship between potency and team effectiveness", Journal of Occupational and Organizational Psychology, Vol 75, pp. 115-119. 
Postmes, T. \& Haslam, S. A, \& Swaab, R. (2005), “Social identity and social influence in small groups: Communication, consensualization and socially shared cognition”, European Review of Social Psychology, Vol 16 pp. 1-42.

Rad, P.F., \& Levin, G. (2003). Achieving project management success using virtual teams. Fort Lauderdale: J.Ross Publishing.

Riggs, M. L., \& Knight. P.A. (1994), “The impact of perceived group on motivational beliefs and attitudes: A causal model”, Journal of Applied Psychology, Vol 79 No 5, pp. 755-766.

Salas, E., Sims, D.E., Klein, C., \& Burke, C.S. (2003), “Can teamwork enhance patient safety?” Forum, Vol 23, pp. 5-9.

Sargent, L.D., \& Sue-Chan, C. (2001), "Does diversity affect group efficacy?" Small Group Research, Vol 32 No 4, pp. 426-450.

Sayles, L. (1958), Behavior of industrial work groups: Prediction and control. Wiley, New York, NY.

Schippers, M.C., Den Hartog, D.N., Koopman, P.L. \& Wienk, J. (2003), “Diversity, Reflexivity and Team Outcomes: The Moderating Effects of Outcome interdependence and group longevity and the mediating effect of reflexivity", Journal of Organizational Behaviour, Vol 24, pp.779-802.

Schön, D. (1983), The Reflective Practitioner. How professionals think in action, Basic Books, London and New York.

Schwenk, C. (1988), "The cognitive dimensions on strategic decision making”, Journal of Management, Vol 25, pp. 41-55.

Shea, G.P., \& Guzzo, R.A. (1987), “Groups as human resources”, Research in Personnel and Human Resources Management, Vol 5, pp.323-356.

Sicotte, H., \& Langley, A. (2000), “Integration Mechanisms and R\&D Performance”, Journal of Engineering and Technology Management, Vol 17 No 1, pp. 1-37.

Sivasubramaniam, N., Murry, W.D., Avolio, B.J., \& Jung, D.I. (2002), “A longitudinal model of the effect of team leadership and group potency on group performance", Group and Organization Management, Vol 27 No 1 pp. 66-96. 
Smith-Jentsch, K.A., Cannon-Bowers, J.A., Tannebaum, S.I., \& Salas, E. (2008), “Guided team selfcorrection", Small Group Research, Vol 39 No 3, pp. 303-327.

Smith-Jentsch, K.A., Mathieu, J.E., \& Kraiger, K. (2005), “Investigating linear and interactive effects of shared mental models on safety and efficiency in a field setting", Journal of Applied Psychology, Vol 90 No 3, pp. 523-535.

Tabachnick, B., \& Fidell, L. (1989), Using Multivariate Statistics, Harper \& Row Publishers, New York.

Tajfel, H. (1978), "Social categorization, social identity and social comparison", in Tajfel, H. (Ed.), Differentiation between social groups: Studies in the social psychology of intergroup relations Academic Press: London. pp. 61-76.

Tjosvold, D., Tang, M.M.L., \& West, M. (2004), "Reflexivity for Team Innovation in China", Group Organization Management, Vol 29, pp.540-559.

Tjosvold, D., (2007), “The conflict positive organization: it depends on us", Journal of Organizational Behaviour, Vol 21 No 9, pp. 19-28.

Tjosvold, D., West, M.A., \& Smith, Og, K. (2003), International Handbook of organizational team work and cooperative working, J Wiley \& Sons, London.

Icmeli-Tukel, O., Rom, W.O. (1998), "Ensuring quality in resource constrained project scheduling", European Journal of Operational Research, Vol. 103, pp.483-96.

Van Dick, R. (2004), “My job is my castle: Identification in organizational contexts”, in Cooper, C.L. \& Robertson, I.T. (Eds.) International Review of Industrial and Organizational Psychology (Vol. 19), Chichester: Wiley. pp. 171-204.

van Knippenberg, D., \& Schippers, M. C. (2007), "Work group diversity”, Annual Review of Psychology, Vol 58, pp. 515-541.

van Knippenberg, D., \& van Schie, E. C. M. (2000), "Foci and correlates of organizational identification”, Journal of Occupational and Organizational Psychology, 73, 137-147. 
Van Knippenberg, D., De Dreu, C.K.W., , \& Homan, A.C. (2004), "Work group diversity and group performance: an integrative model and research agenda", Journal of Applied Psychology, Vol 89, 1008-1022.

Vera, D., \& Crossan, M. (2005), “Improvisation and Innovative Performance in Teams, Organization Science”, Vol. 16, No. 3, pp. 203-224.

Watson, C.B., Chemers, M.M., \& Prieser, N. (2001), “Collective efficacy: A multilevel analysis", Personality and Social Psychology Bulletin, Vol 8, pp.1057-1068.

Webber, S. S., Chen, G., Payne, S. C., Marsh, S. M., \& Zaccaro, S. J. (2000), “Enhancing team mental model measurement with performance appraisal practices", Organizational Research Methods, Vol 3, pp. 307-322.

Weick, K., and K. H. Roberts (1993), “Collective mind in organizations: heedful interrelating on flight decks”. Administrative Science Quarterly, Vol 38, pp.357-381.

West, M.A., \& Markiewicz, L. (2003), Building team based working: A practical guide to organizational transformation, Blackwell, BPS: London.

West, M.A. (1996), The Handbook of Work Group Psychology, Wiley: Chichester.

West, M.A. (2000), "Reflexivity, revolution and innovation in work teams”, In M.M. Beyerlein, M.M., Johnson, D.A., \& Beyerlein, S.T. (Eds.), Product Development Teams. JAI Press, Stamford, Connecticut.

Yearta, S., Maitlis, S., \& Briner, R.B. (1995), “Goal setting theory: A motivational theory that really works?” Journal of Occupational and Organizational Psychology, Vol 68, pp. 237-252.

Yen, J., Fan, X., Sun, S., Hanratty, T., \& Dumer, J. (2006), “Agents with shared mental models for enhancing team decision making. Decision support systems”, pp.634-653

Zaccaro, S.J., Blair, V., Peterson, C., \& Zazanis, M. (1995), “Collective efficacy”, in Maddux, J.E. (Ed.), Self-efficacy, adaptation, and adjustment: Theory, research, and application, Plenum Press, New York. Pp. 305-328. 
Figure 1 Propositional Model of Self-Regulated Team Work

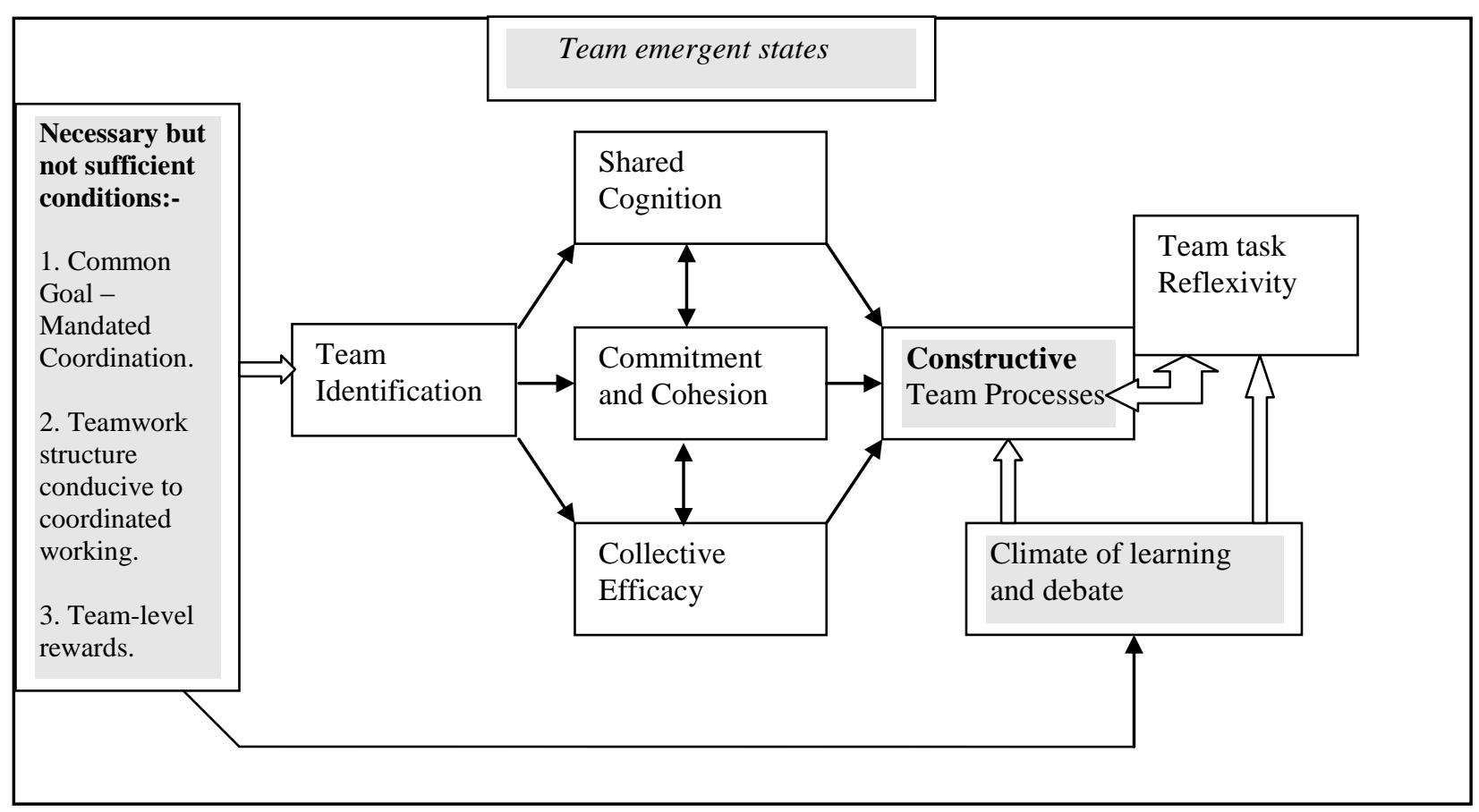


Figure 2 A Process Oriented Model of Team Development

\begin{tabular}{|c|c|}
\hline Team Processes e.g., & Team Effectiveness \\
Communication & Measured by: \\
Social interaction & Process indicators \\
Role Clarification & Attitude indicators \\
Goal Setting & \\
\hline
\end{tabular}

\section{Team Building}

Aims to re-engineer behavioural processes

Focus on symptoms of team

Ignores the causes of team

effectiveness 
Figure 3 A Generative Model for Team Development

\begin{tabular}{|c|c|c|}
\hline $\begin{array}{l}\text { Structural } \\
\text { Prerequisites } \\
\text { 1.Mandate to } \\
\text { coordinate in } \\
\text { relation to } \\
\text { common goal }\end{array}$ & $\begin{array}{c}\text { Team Causes } \\
\text { Shared Mental Models } \\
\text { Team Reflexivity } \\
\text { Team Identification \& Collective } \\
\text { efficacy }\end{array}$ & $\begin{array}{c}\text { Team Processes } \\
\text { Self-Regulated according to requirement } \\
\text { Team retains diagnostic prerogative }\end{array}$ \\
\hline $\begin{array}{l}\text { 2. Structure that is } \\
\text { conducive to } \\
\text { teamwork }\end{array}$ & & \\
\hline $\begin{array}{l}\text { 3. Team Level } \\
\text { rewards }\end{array}$ & $\begin{array}{l}\text { Team Building } \\
\text { Aims to develop team self- } \\
\text { regulatory ability via cognitive- } \\
\text { motivational mechanisms }\end{array}$ & $\begin{array}{l}\text { Team Effectiveness } \\
\text { e.g. Measured by - } \\
\text { Results }\end{array}$ \\
\hline
\end{tabular}




\section{Appendix 1 Operational Implications for Team Development}

Factors that will promote team focus and orientation:-

- Knowledge of team function and contribution to wider organizational goals, of 'teams' and what makes them tick, including the benefits of team work.

- Establishment of perceptions of co-operative interdependence among team members by setting up behavioural imperatives (e.g. by task organization, superordinate goals, and the way the team is rewarded).

- The establishment of a salient team categorisation and meaningful team identity (Mael and Ashforth, 1992) by establishing a win/lose (i.e. competitive interdependence at the team level) or win/win intergroup orientation (i.e. co-operative interdependence as in the 'partnership model'), facilitating the development of positive team distinctiveness, and importance or prestige (Carron and Spink, 1993), and the development of a team ideology or sense of mission (promoted by goal-setting), and facilitating the recall and documentation of prior team achievement/success not only to achieve a sense of continuity but to heighten collective self-esteem and confidence in its ability to succeed in the future.

- The establishment of salient personal goals in connection with team goals which members accept and to which they are committed. Role clarification may be part and parcel of raising accountability perceptions.

Team Competence can be developed by:-

Providing a forum in which the team can develop an explicit and realistic knowledge of itself as a team This will promote knowledge of team imperatives, acknowledging the wider context, the internal composition of the team (roles, personal characteristics, skill and knowledge distribution), team strengths and weaknesses, team goals/mission, its culture/climate, situational awareness (i.e., ability to detect and also to respond appropriately to variations in the context surrounding team work), and team experiences of what works and what does not, of team process and how it can be adapted to the situation at hand. The diagnostic/analytical process will also challenge existing behaviours that are not conducive to optimal team functioning.

Providing a forum in which the team can develop self-regulatory skill.

This will promote an ability of the team to 'diagnose' its own process requirement, to analyse and scope out problems of both a task and team nature, to monitor and manipulate its own processes in a selfreflexive way, to 'capture' and apply new learning. It also involves promoting the team's ability to perpetuate and maintain itself over time despite turnover/attrition by distributing team knowledge/experience/learning within and across the team as a whole.

Providing a forum in which team 'success experiences' are recalled and/or created.

The team can be helped to recall success experiences within the history of the team (or within the history of team members in other team contexts if the team does not have much of a history to draw upon), to document and use them as the basis for promoting future success. Building success experiences can be done by the judicious use of (in-situ/off-site) team problem solving exercises whereby team data is readily available for feedback purposes. 